Pak. j. sci. ind. res. Ser. A: phys. sci. 2018 61A(2) 96-99

\title{
Characterisation of Patala Formation Coal Reserves of Salt Range and its Application
}

\author{
Hafiz Muhammad Zulfiqar Ali ${ }^{\text {** }}$, Aun Zahoor ${ }^{\text {a }}$ Hafiz Muhammad Zaheer Afzal ${ }^{\mathrm{a}}$ \\ and Muhammad Yasin ${ }^{\mathrm{b}}$ \\ ${ }^{a}$ Geological Survey of Pakistan, Sariab Road, Quetta, Pakistan \\ ${ }^{\mathrm{b}}$ Space and Upper Atmosphere Research Commission, Quetta Cantt, Pakistan \\ (received May 23, 2017; revised November 17, 2017; accepted March 5, 2018)
}

\begin{abstract}
Early Paleocene Patala Formation in Central Salt-Range of Punjab, Pakistan is known for hosting vast reserves of lignite coal. The coal seams located at the depth of about $145 \mathrm{~m}$, mined out through underground mining method. As many as 17 samples have been taken from Wahula (Site-I), Dandot (Site-II) and Padhrar (Site-III) areas, with active mining of Salt Range, and on the basis of the results of the two laboratory techniques viz. Proximate Lab Analysis and Ultimate Lab Analysis, the coal has been attributed to be of Lignite class. The Proximate analysis of the samples put the percentage of fix carbon ranges at 21.39 to $28.26 \%$ for S-I, 15.54 to $25.32 \%$ for S-II and 18.52 to $28.37 \%$ for S-III, whereas, the gross calorific value (GCV) found out to be in ranges: 3078 to 4443,2285 to 4963 and 3429 to $3665 \mathrm{Kcal} / \mathrm{kg}$, respectively. Likewise, the total carbon percentage (TCP)- worked out with the help of the Ultimate Analysis - are $54.36 \%, 50.05 \%$ and $47.4 \%$ for these three sites accordingly. Sulphur contact ranges from 3.3 to $10.35 \%$ is, generally, associated with coal deposits present in salt range, and due to this high sulphur content its utility is restricted to cement industries, brick plants, coal boiler and briquetting. This study, however, suggests that the blending of this lignite coal with limestone and high-grade coal can enable it to be used in coal-fired power generation plants, steel mills as well as liquid fuel.
\end{abstract}

Keywords: coal characterisation, Patala formation, salt range, industrial application

\section{Introduction}

The coal deposits, available within the territorial jurisdiction of the Punjab province of Pakistan, belong to Permian and Paleocene age. The Permian coal-rather sparsely available compared to that of Paleocene age (Tertiary era) is mined out in suburbs of district Mianwali of western salt range whereas the Patala formation of Late Paleocene in central and eastern salt range and Hangu formation of early Paleocene age in Makerwal region and Surghar range contain abundant occurrence of the Tertiary coal which is being mined out from different localities within these areas.

This research work aims at the Tertiary coal of Patala formation being mined out in the areas of Wahula (S-I) district Chakwal, Dandot (S-II) and Padhrar (S-III) district Khushab in central salt range by a Provincial Government Agency namely Punjab Mineral Development Corporation (PMDC) that, for operational needs, has divided each site into several subunits consisting of group of mines (Fig. 1-2).

*Author for correspondence;

E-mail: hzpakgeologist@gmail.com
Geological settings. Lithologically, the Late Paleocene Patala formation in Upper Indus Basin contains Calcareous Shale with alternative coal seams whereas, in study area it comprises of Greenish Grey Carbonaceous Shale with occasional Pyritic nodules; marl and white to grey nodular limestone while coal is present in abundance in middle part of the rock unit.

The town of Balkasar has the type-locality of the Patala formation where it is 27 to 109 meters thick and make topographic depressions and gentle inclines. Its lower contact with early Permian Warch Sandstone is Unconformable and is marked by a Muscovite bearing Lateritic band while it has conformably transitional upper contact with Middle Eocene Nammal formation. The Foraminifera fossils are found in abundance in Patala formation with Assilina nautilus, Montlivaittia and Rhotalia are the common species that make the premise for the age attributed to it i.e., Late Paleocene. Fatmi (1973) describes the Patala formation to have deposited in Marine to lagoonal setting. While, more recently a detailed work by Kazmi and Abbasi (2008) suggested an off-shore back barrier depositional set-up for it. 
Methodology. The laboratory analyses were performed on all coal samples in strict compliance to the pertinent ASTM codes viz. ASTM D 4749 for sieve analysis, ASTM D 3173 for percentage moisture contents (MC) (\%), ASTM D 3175 volatile matter (VM) (\%) and ASTM D 3174 for ash contents (AC) (\%). Fix carbon percentage was calculated using simple arithmetic (sum of MC, VM and AC subtracted from 100). The ultimate analysis on the samples was conducted following the instructions as laid down under ASTM D 5373-08.

\section{Results and Discussion}

Under proximate-analysis (Table 1) all of the (17) specimens were tested for moisture contents (MC), volatile matter (VM), fixed carbon (FC) and ash contents (AC), while, under elemental analysis (Table 2)

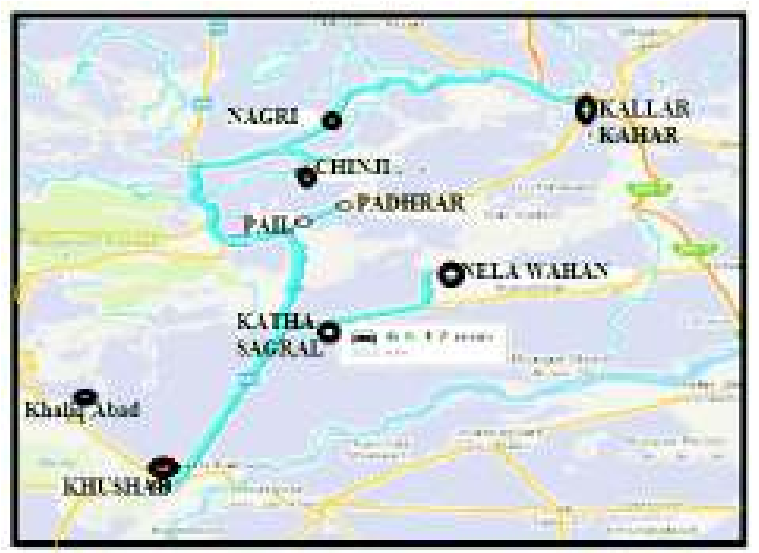

Fig. 1. Showing Site-III with attached areas.

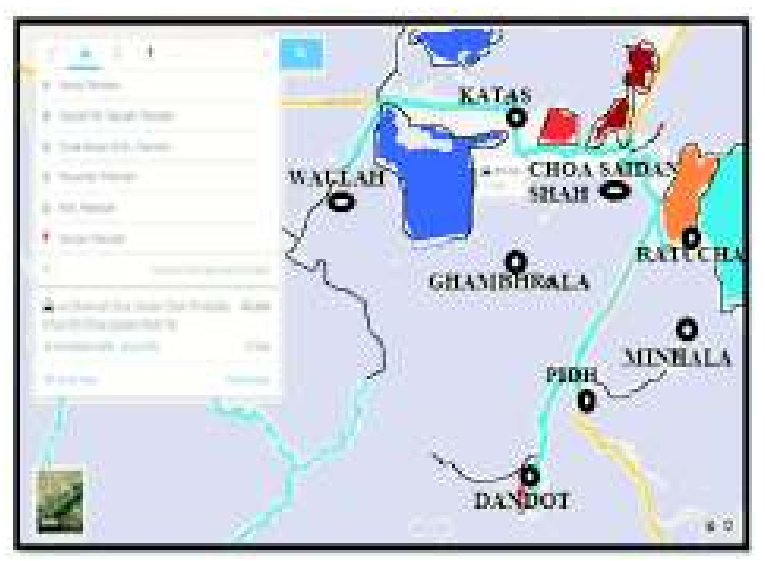

Fig. 2. Displaying Site I and II with adjacent place. percentages of hydrogen, nitrogen, sulphur and oxygen present in the samples were evaluated so as to determine the suitability of this coal for various industrial and applied purposes.

Table 1. Proximate analysis of Patala formation coal reserves salt range

\begin{tabular}{llllll}
\hline \hline $\begin{array}{l}\text { Study } \\
\text { area } \\
\text { (site) }\end{array}$ & $\begin{array}{l}\text { Moisture } \\
\text { contents }\end{array}$ & $\begin{array}{l}\text { Ash } \\
\text { contents }\end{array}$ & $\begin{array}{l}\text { Volatile } \\
\text { matter }\end{array}$ & $\begin{array}{l}\text { Fix } \\
\text { carbon }\end{array}$ & $\begin{array}{l}\text { GCV } \\
\mathrm{kcal} / \mathrm{kg}\end{array}$ \\
\cline { 2 - 5 } & \multicolumn{5}{c}{$(\%)$} \\
Site-III & 5.07 & 42.33 & 27.64 & 25.06 & 3884 \\
Site-II & 6.26 & 49.44 & 24.25 & 20.12 & 3298 \\
Site-I & 5.14 & 43.20 & 22.75 & 22.75 & 3959 \\
Average & 5.49 & 44.99 & 24.88 & 22.64 & 3713 \\
value & & & & \\
\hline \hline
\end{tabular}

Table 2. Ultimate analysis of Patala formation coal reserves salt range

\begin{tabular}{llllll}
\hline \hline $\begin{array}{l}\text { Project } \\
\text { Name }\end{array}$ & Carbon & Hydrogen & Nitrogen & Sulphur & Oxygen \\
\cline { 2 - 6 } & \multicolumn{5}{c}{$(\%)$} \\
\hline Site-III & 54.36 & 4.5 & 1.06 & 9.31 & 14.45 \\
Site-II & 50.05 & 5.3 & 0.97 & 5.22 & 18.3 \\
Site-I & 47.4 & 4.9 & 0.83 & 4.20 & 16.3 \\
$\begin{array}{l}\text { Average } \\
\text { value }\end{array}$ & 50.60 & 4.9 & 0.95 & 6.24 & 16.35 \\
\hline \hline
\end{tabular}

Table 3. Coal classification reference standards based on C, H \& O \% after Perry (1963)

\begin{tabular}{lllll}
\hline \hline Parameters & Peat & Lignite & Bituminous & Anthracite \\
\hline $\mathrm{C}$ & 50 & 65 & 88 & 94 \\
$\mathrm{H}$ & 5.9 & 5.2 & 4.6 & 3.4 \\
$\mathrm{O}$ & 34 & 28 & 7 & 2.5 \\
\hline \hline
\end{tabular}

Table 4. Apparent density of Patala formation coal salt range $(\mathrm{g} / \mathrm{mL})$

\begin{tabular}{llll}
\hline \hline $\begin{array}{l}\text { Sample } \\
\text { No. }\end{array}$ & $\begin{array}{l}\text { Site-III } \\
\text { (Padhrar) }\end{array}$ & $\begin{array}{l}\text { Site-II } \\
\text { (Dandot) }\end{array}$ & $\begin{array}{l}\text { Site-I } \\
\text { (Wahula) }\end{array}$ \\
\hline 1 & 1.351 & 1.333 & 1.325 \\
2 & 1.365 & 1.351 & 1.341 \\
3 & 1.357 & 1.357 & 1.317 \\
Average & 1.357 & 1.347 & 1.327 \\
value & & & \\
\hline \hline
\end{tabular}

Apparent density value of the samples from three sites (S-III, S-II, S-I) varies from 1.327 to $1.357 \mathrm{~g} / \mathrm{mL}$, as S-III $>$ S-II $>$ S-I. 
Table 5. Application of low quality coal in industrial sectors

\begin{tabular}{|c|c|c|}
\hline Utilization & Type of coal & Present research remarks \\
\hline Power generation & Bituminous and sub bituminous & $\begin{array}{l}\text { Coal of Site-I can be applicable by blending with high rank coal and } \\
\text { limestone. }\end{array}$ \\
\hline Steel production & Low sulfur coal & The coal of all 3 sites may be used only after desulphurization. \\
\hline Liquid fuel & Low sulfur and nitrogen & Suitable after the calculation of $\mathrm{N}$ values and desulphurization \\
\hline Coal boiler & Lignite and bituminous mixture & Valid for all kinds of coal boilers by mixing with $\mathrm{CaCo}_{3}$ \\
\hline Briquetting & Lignite & Adequate for coal briquetting \\
\hline Brick plant & Lignite and sub bituminous & Appropriate for brick factory \\
\hline Domestic & Bituminous and anthracite & May create serious health issues due to high \% of sulphur \\
\hline Cement factory & Lignite and sub bituminous & Acceptable for cement industries \\
\hline
\end{tabular}

On average the percentage of carbon in the samples, as found out by elemental analysis is $50.60 \%$ which is dismally low. A comparison of three sites indicate that percentage of carbon is maximum i.e., $54.36 \%$ in samples from site-III (Padhrar area) and minimum i.e., $47.4 \%$ in samples collected from site-I (Wahula areas). The sulphur content an undesired element as far as coal quality is concerned, however, also follows the same pattern with site-III bears the highest value i.e., 9.31\% and site-I bears lowest i.e., $4.20 \%$. The average sulphur value for all the samples combined stands as high as $6.24 \%$ which speaks volumes of the unsuitability of this coal for any advance industrial use unless treated appropriately.

Coal categorized in anthracite, bituminous and lignite ranks depending on the value of $\mathrm{C}, \mathrm{H}$ and $\mathrm{O}$ contents after Perry's reference coal analysis table as given in Table 3 (Ismat, 2013).

The results of the elemental analysis, when compared to the reference values as given in Table 3 made it evidently clear that the coal present in Patala Formation in central salt range qualifies hardly to be Lignite or in stricter sense actually stands between Peat and Lignite categories of Perry's classification.

\section{Conclusion and recommendations}

- The coal quality of Patala formation (Late Paleocene) of eastern and central salt range, Punjab province is categorized as Lignite (Low quality).

- Average value of GCV of eastern and central salt range is $3656 \mathrm{Kcal} / \mathrm{kg}$, but it changes from 2853 to $4973 \mathrm{Kcal} / \mathrm{kg}$.

- Ultimate analysis of salt range coal deposits provides the average percentage of $\mathrm{C}, \mathrm{H}, \mathrm{N}$ and $\mathrm{O}$ as 50.60, 4.9, 0.95 and 16.35 , respectively.

- General the coal reserves of salt range comprises high proportion of volatile matter, ash, and sulphur varies from 23.56 to $34.74 \%, 40.32$ to $63.21 \%$ and 3.91 to $10.4 \%$, correspondingly.

- Coal deposits of Patala formation contains appropriate percentage of moisture which fluctuates from 4.32 to 9.28 .

- Salt range coal reserves of Punjab province could be precisely applicable in all varieties of coal boiler, brick plant, briquetting, cement factories, paper mills and chemical industries.

- Patala formation coal of salt range contains high percentage of sulphur, so it might be utilized in power generation and steel industries after blending with high quality coal and desulphurization.

- It is endorsed that homegrown coal deposits of Patala formation can be consumed in coal fired power plants by combination with high rank coal, to overwhelmed the energy adversities.

\section{References}

Ahmed, W., Gauher, S.H., Siddiqi, R.A. 1986. Coal resources of Pakistan. Geological Survey of Pakistan Record, 73: 55-63.

ASTM, 2002. Annual Book of ASTM Standards. American Society for Testing and Materials, PA, USA.

Bhatti, N.A. 1967. Occurrence of Permian coal near Burikhel, Western Salt Rnge. Geological Survey of Pakistan, Unpublished Report. pp. 21-32.

Fatmi, A.N. 1973. Depositional environment of Paleocene rocks, Pakistan. 
Fazeelat, T., Asif, M. 2004. Organic geochemical study of lignite coal from Pakistan. Journal of Chemical Science, 27: 199-204.

Irshad, M., Ahmad, I., Shakirullah, M., Bahader, A., Taj, N. 2002. Charcterization of Khushab Coal (Punjab Pakistan). Journal of Chemical Science Pakistan, 24: 240-245.

Ismat, A. 2013. Some Studies on Coal Briquetting, pp. 40-44, Fuel Research Centre, PCSIR, Karachi, Pakistan.

Khan, M.S., Gillani, S.T., Iqbal, M.M. 2011. Estimation of drainage mine drainage (AMD) from coal mines and its management. Journal of Faculty of Engineering and Technology, 18: 47-57.

Malkani, M.S. 2004. Coal resources of Chamalang, Bahney Wali and Nosham-Bahlol areas of Kohlu, Barkhan, Loralai and Musa Khel districts, Balochistan, Pakistan. In: Abstract Volume National Conference on Economic and Environmental Sustainability of Mineral Resources of Pakistan, Baragali, Pakistan, pp. 44-45.

Mehmood, R., Habib, M., Bhatti, M.A., Yousaf, A. Underground Coal Gasification (UCG) studies on Chakwal Coal, Punjab province, Pakistan. PCSIR Laboratory Complex Lahore. 54: 117-122.

Shah, S.M.I. 1990. Coal resources of Baluchistan and significance of the coal resources of Pakistan, GSP-USGS, pp. 63-92.

Siddiqui, I., Soomro, A.S., Agheem, M.H. 2012. Comparative chemical and mineral characterization of Paleocene coal of Sonda coalfield, Sindh, Pakistan. Mehran University Research Journal of Engineering and Technology, 32: 585-593.

Warwick, P.D., Shakoor, T. 1988. Preliminary report on coal deposits of Salt Range. USGS Project Report, (IR), PK-83, 333 pp. 